\title{
Vitamin D Receptor Gene Polymorphisms Influence T1D Susceptibility among Pakistanis
}

\author{
Maryam Mukhtar, ${ }^{1}$ Andleeb Batool, ${ }^{1}$ Abdul Wajid, ${ }^{2}$ and Iram Qayyum ${ }^{1}$ \\ ${ }^{1}$ Department of Zoology, G.C. University, Punjab, Lahore 54000, Pakistan \\ ${ }^{2}$ Department of Biotechnology, Virtual University of Pakistan, 1-Davis Road Lahore 54000, Pakistan \\ Correspondence should be addressed to Maryam Mukhtar; m.mukhtar29@gmail.com
}

Received 6 April 2017; Revised 22 September 2017; Accepted 2 October 2017; Published 3 December 2017

Academic Editor: Margarita Hadzopoulou-Cladaras

Copyright (c) 2017 Maryam Mukhtar et al. This is an open access article distributed under the Creative Commons Attribution License, which permits unrestricted use, distribution, and reproduction in any medium, provided the original work is properly cited.

\begin{abstract}
Background. The vitamin D receptor (VDR) gene regulates insulin secretion from the pancreas and acts as a mediator of the immune response through vitamin D. Polymorphism in VDR causes alterations in the functioning of vitamin $\mathrm{D}$, leading to type 1 diabetes (T1D) predisposition. The aim of the present study was to determine VDR gene polymorphism in association with T1D in Pakistanis. Methods. The association was evaluated by selecting rs2228570 (FokI), rs7975232 (ApaI), and rs731236 (TaqI) polymorphic sites in 102 patients and 100 controls. Genotypes were identified by DNA sequencing and PCR-RFLP. Results. The allelic and genotypic frequencies of FokI and ApaI were significantly associated with T1D $(p<0.001)$ development. At the FokI site, tryptophan was replaced with arginine due to polymorphism. A novel SNP (GeneBank acc number KT280406) was identified through the sequencing of intron $8,62 \mathrm{bp}$ downstream from the ApaI polymorphic site, and significantly associated with T1D development. The TaqI did not depict any association with T1D at the allelic or genotypic level $(p>0.05)$. CCGC, CCGG, CCTC, and CCTG haplotypes were significantly associated with disease development $(p<0.05)$. However, CTGG haplotype was protective towards T1D $(p<0.01)$. Conclusion. VDR polymorphisms were identified as susceptible regions for T1D development in the Pakistani population.
\end{abstract}

\section{Introduction}

T1D is a polygenic disease with several protective and susceptible alleles interacting with each other [1]. Genetics plays a key role in the onset of T1D $[2,3]$ and shows a significant clustering in a family; as in siblings, the average risk prevalence is $6 \%$ as compared to the general population with a $0.6 \%$ risk [4].

Vitamin D displays vital immunomodulatory properties that aid in preventing diabetes development in T1D animal models [5]. It activates human macrophages, antigenpresenting cell maturation, and inhibits dendritic cell differentiation as well as affects cytokine production by interacting with most immune cells $[6,7]$. Vitamin D reduced the MHC class I molecules and Fas expression (transmembrane cell surface receptor mediator) leading to the suppression of pancreatic $\beta$-cell apoptosis $[8,9]$. In addition, it increases A20 protein expression, which has an antiapoptotic function against pancreatic $\beta$-cells, and increases insulin production [9].

Vitamin D is reported to be metabolically active and activates the nuclear vitamin $\mathrm{D}$ receptors $(V D R)$ to exert its genomic effect. The VDR belongs to the super family of ligand-activated transcription factors located on the 12q12-q14 chromosome and encoded by the VDR gene in humans [10]. It consists of two promoter regions, six untranslated exons (exons 1a-1f) that are spliced alternatively, and eight protein-coding exons (exons 2-9) [11]. Basically, the $V D R$ gene contains four polymorphism sites which were identified with restriction fragment length polymorphism (RFLPs) TaqI within exon 9, ApaI and BsmI within intron 8, FokI within exon 2, and mononucleotide polymorphism in the $3^{\prime}$ untranslated region [12]. In our previous study, two SNPs: rs1544410 on VDR and rs2476601 on PTPN22 were screened and were found significantly associated with T1D in the Pakistani population [13]. The genomic action of 
TABLE 1: Clinical parameters of the individuals.

\begin{tabular}{lcccc}
\hline \multirow{2}{*}{ Parameters } & \multicolumn{2}{c}{ Patient $(n=102)$} & \multicolumn{2}{c}{ Control $(n=100)$} \\
& $\begin{array}{c}\text { Male } \\
(n=54)\end{array}$ & $\begin{array}{c}\text { Female } \\
(n=48)\end{array}$ & $\begin{array}{c}\text { Male } \\
(n=52)\end{array}$ & $\begin{array}{c}\text { Female } \\
(n=52)\end{array}$ \\
\hline Age (years) & 12.5 & 14.05 & 13.40 & 14.13 \\
Age of diagnosis (years) & 4.35 & 5.02 & 0 & 0 \\
Positive family history & $52 \%$ & $70 \%$ & $0 \%$ & $0 \%$ \\
Physical activity & $44.83 \%$ & $27.3 \%$ & $100 \%$ & $100 \%$ \\
\hline
\end{tabular}

vitamin $\mathrm{D}$ is initiated by its binding to the $V D R$, which leads to the transcription of genes regulated by it. This transcriptional regulation occurs to a very complicated mechanism [14].

The Pakistani population is heterogeneous and becoming more complex due to cast-specific marriages. This phenomenon produces narrow genetic pool and transfers the genetic mutations more often to the next generations. Therefore, the current study was designed to evaluate the association of polymorphism in the VDR gene with T1D.

\section{Methods}

2.1. Subjects. The study was ethically approved by the Board of Advance Research, G.C. University, Lahore, Pakistan. This case-control study was carried on T1D patients recruited from the Diabetic Center of Shalamar Hospital, Lahore (public sector hospital). Written consent was obtained from patients/guardians of the studied subjects. All patients that participated were already clinically diagnosed with T1D by a physician according to WHO criteria such as hyperglycemia, insulin requirement from diagnosis, recurrent infections, high levels of glycosuria, increased urine volume and thirst, unexplained weight loss, and in severe cases coma and drowsiness [15]. A total of 102 T1D cases and 100 controls were included in the study. The clinical characteristics (gender, age, the age of diagnosis, and positive family history as well as physical activity including exercise and playing outdoor games) that were recorded after interviewing the patients who participated in the study were presented in Table 1 . All control subjects were healthy and had a negative family history of T1D.

2.2. DNA Isolation and SNP Selection. Blood samples ( $3 \mathrm{ml})$ from each subject were collected in EDTA-coated tubes, and DNA was extracted by the modified organic extraction method [16]. The extracted DNA was stored at $-20^{\circ} \mathrm{C}$ (Haier) for further genetic analysis. DNA quantification was carried out by the nanodrop (Thermo 2000). Three polymorphic sites FokI, ApaI, and TaqI were selected by using the HapMap database (http://hapmap.ncbi.nlm.nih.gov/) and SNP Browser software 4.0 (Applied Biosystems).

2.3. Polymerase Chain Reaction. The DNA was amplified for polymerase chain reaction (PCR) in a $25 \mu \mathrm{l}$ reaction mixture by using already reported primers (Israni et al., [17]). The following primers were used: for FokI (rs2228570) forward primer (F): $5^{\prime}$-AGCTGGCCCTGGCACTGACTCTGGCT CT $-3^{\prime}$ and reverse primer (R): $3^{\prime}$-ATGGAAACACCTTGCT

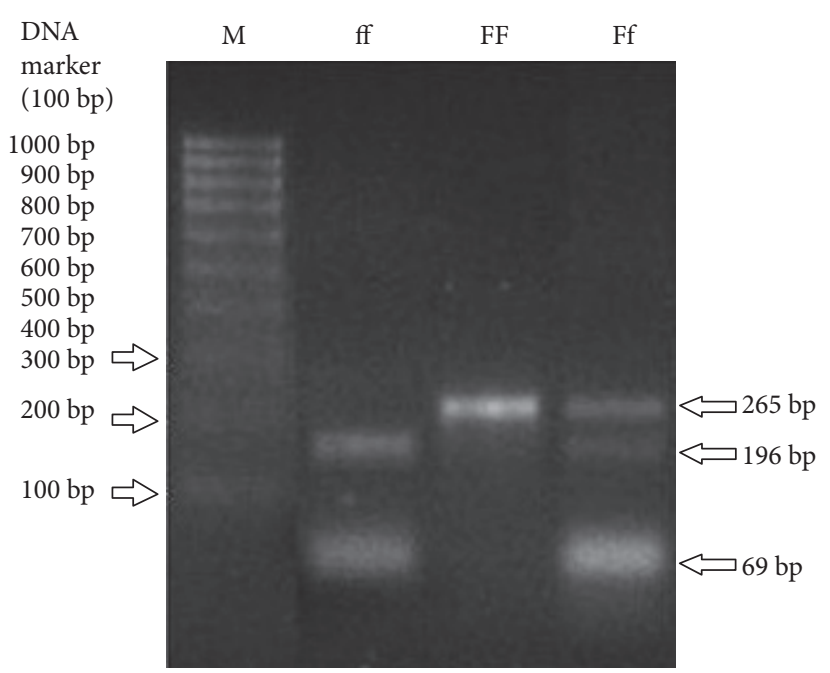

Figure 1: FokI digestion (SNP C/T) in exon 2: Restriction site presence is designated by " $\mathrm{f}$," and absence is designated by " $\mathrm{F}$." ff (CC), for example, a $196 \mathrm{bp}$ and $69 \mathrm{bp}$; Ff (CT), for example, $265 \mathrm{bp}, 196 \mathrm{bp}$, and $69 \mathrm{bp}$, bands; FF (TT), for example, $196 \mathrm{bp}$ and $69 \mathrm{bp}$ bands.

TCTTCTCCCTC-5' , for TaqI (rs731236), ApaI (rs7975232), and KT280406 F: $5^{\prime}$-CAGAGCATGGACAGGGAGCAA-3' and R: $3^{\prime}$-GCAACTCCTCATGGCTGAGGTCTC-5'. The PCR was carried out for 30 cycles, which consists of initial denaturation at $94^{\circ} \mathrm{C}$ for $5 \mathrm{~min}$, denaturation at $94^{\circ} \mathrm{C}$ for $45 \mathrm{~s}$, annealing at $68^{\circ} \mathrm{C}(F o k \mathrm{I})$ and $65^{\circ} \mathrm{C}(\mathrm{TaqI}$ and $A p a \mathrm{I})$ for $45 \mathrm{~s}$, and extension at $72^{\circ} \mathrm{C}$ for $30 \mathrm{~s}$ followed by final extension at $72^{\circ} \mathrm{C}$ for 10 mins.

2.4. VDR Genotyping. VDR genotyping for FokI, ApaI, and TaqI was performed by DNA sequencing and restriction fragment length polymorphism (RFLP), whereas for KT280406, all samples were sequenced with forward primer. For sequencing, the reaction mixture of $10 \mu \mathrm{l}$ was prepared to contain $3 \mu \mathrm{l}$ of purified PCR product, $1 \mu \mathrm{l}$ of forward primer, $1 \mu \mathrm{l}$ of big dye mixture, $1 \mu \mathrm{l}$ of $5 \mathrm{X}$ reaction buffer, and $4 \mu \mathrm{l}$ of DEPC water. The products were amplified by following PCR conditions: initial denaturation at $95^{\circ} \mathrm{C}$ for 2 mins followed by repeated 35 cycles of denaturation at $95^{\circ} \mathrm{C}$ for $30 \mathrm{~s}$, annealing at $50^{\circ} \mathrm{C}$ for $15 \mathrm{~s}$, and extension at $60^{\circ} \mathrm{C}$ for 4 mins, and at end final extension at $60^{\circ} \mathrm{C}$ for 5 mins. By using isopropanol, amplified PCR products were precipitated. Product pellets were dissolved in $12 \mu \mathrm{l}$ formamide and were incubated for 5 minutes at $95^{\circ} \mathrm{C}$ and chilled quickly. The samples were loaded to ABI PRISM genetic analyzer $3130 \mathrm{XL}$ to sequence the fragment of interest. The samples were visualized by sequencing software $\mathrm{V}$ 3.7 and Bio Edit software, and mutations were determined (Supplementary Figures 1 available online at https://doi. org/10.1155/2017/4171254, 2, and 3) and were confirmed by NCBI BLAST (Supplementary Figure 4 ).

For PCR-RFLP, according to the manufacturer's instructions, the PCR products were digested using restriction enzymes; BseGI (FokI) (Fermentas, Germany), ApaI, and TaqI (Vivantis). Briefly, $10 \mu \mathrm{l}$ of each PCR product was 
TABLE 2: Single site test of genetic variants in T1D and controls.

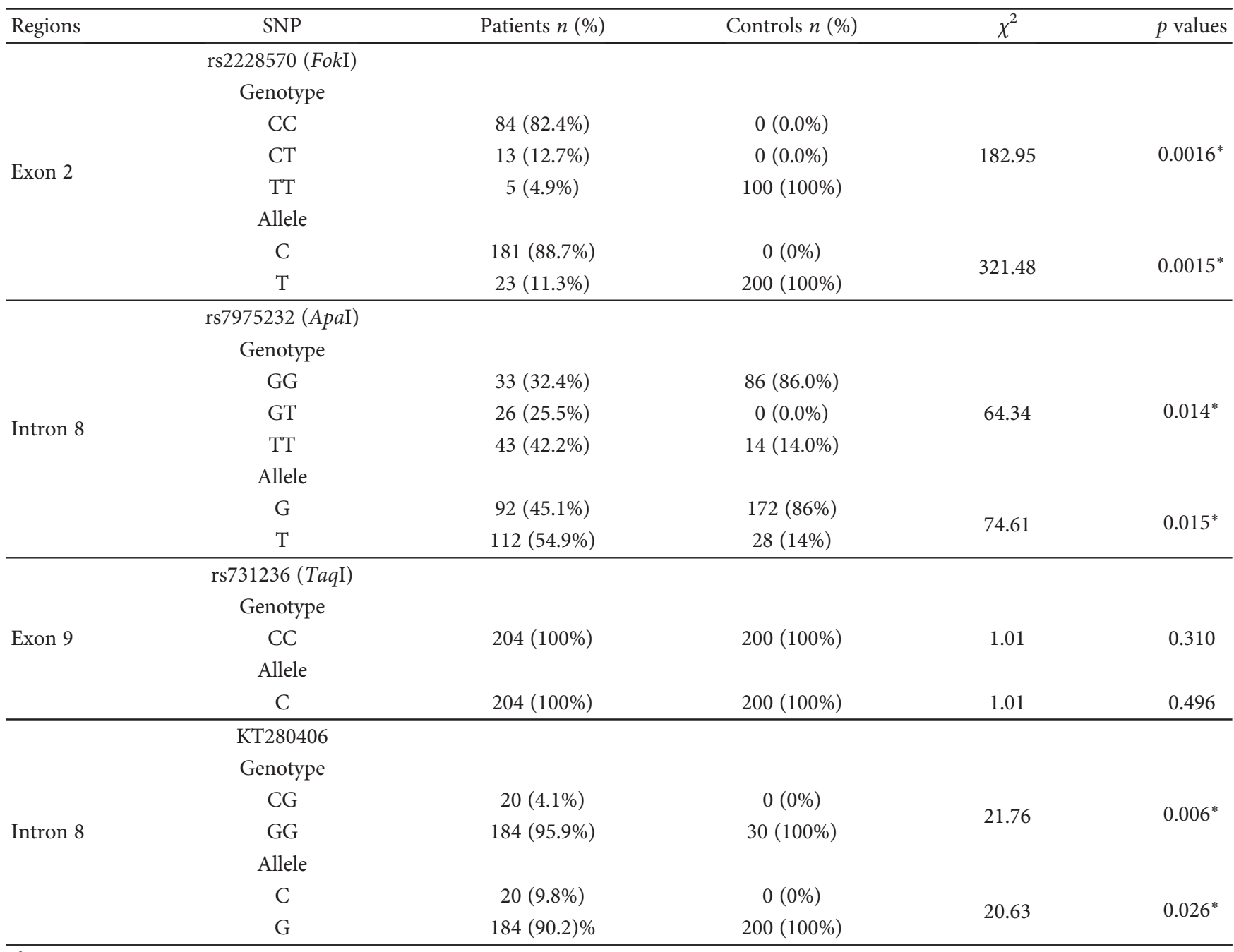

$\chi^{2}$ : chi-square test; $*$ represents significance at the 0.05 level.

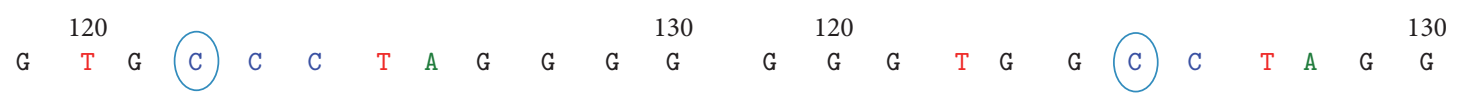

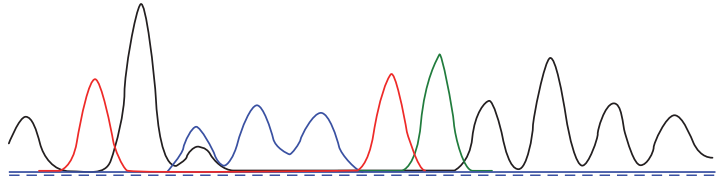

(a)

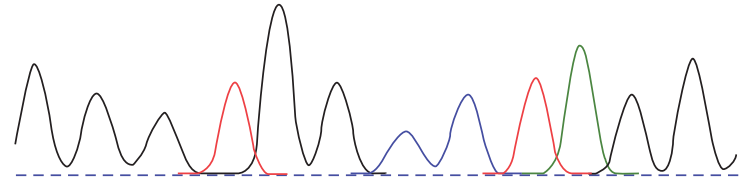

(b)

Figure 2: Representation of novel mutation identified at intron 8. (a) Patient genotype (GC) and (b) control genotype (GG).

mixed with $2 \mu \mathrm{l}$ of Tango buffer, $1 \mu \mathrm{l}$ of restriction enzyme, and $12 \mu \mathrm{l}$ of DEPC water. The tubes were incubated at $55^{\circ} \mathrm{C}$ for $5 \mathrm{~h}\left(\right.$ FokI), $55^{\circ} \mathrm{C}$ for $3 \mathrm{~h}\left(\right.$ TaqI), and at $37^{\circ} \mathrm{C}$ for $16 \mathrm{~h}$ (ApaI); followed by thermal inactivation of restriction enzymes at $80^{\circ} \mathrm{C}(F o k \mathrm{I}), 80^{\circ} \mathrm{C}($ TaqI $)$, and $65^{\circ} \mathrm{C}$ (ApaI) for 20 mins. Digested samples were run on $2 \%$ agarose gel and visualized on the gel documentation system (BioDoc-It Imaging System, Figure 1).

2.5. Statistical Analysis. All data of the controls passed the Hardy-Weinberg equilibrium $(p>0.05)$. The chi-square test was used to determine allelic and genotypic frequencies. 
TABLE 3: Haplotype analysis of the VDR gene located on chromosome 12 .

\begin{tabular}{lccc}
\hline $\begin{array}{l}\text { Haplotype } \\
\text { (rs731236-rs2228570- } \\
\text { rs7975232-KT280406) }\end{array}$ & Case (freq) & Control (freq) & $p$ value \\
\hline CTGG & 0.046 & 0.860 & $0.001^{\odot}$ \\
CTTG & 0.054 & 0.014 & $0.004^{\circledast े}$ \\
CCGC & 0.035 & 0.000 & $0.007^{*}$ \\
CCGG & 0.368 & 0.000 & $0.002^{*}$ \\
CCTC & 0.051 & 0.000 & $0.001^{*}$ \\
CCTG & 0.434 & 0.000 & $0.006^{*}$ \\
\hline
\end{tabular}

* represents a significant association of haplotypes with T1D. represents a significant association of haplotypes protective against T1D.

Linkage disequilibrium and haplotypes were calculated to study their association with T1D by SHEsis (http:// analysis.bio-x.cn/SHEsisMain.htm). The change in amino acid sequences was determined by aligning sequences in Mega 6 software.

\section{Results}

The allelic and genotype frequencies of the VDR gene at FokI, ApaI, and TaqI polymorphic sites were assessed in 102 T1D patients and 100 controls and were presented in Table 2. In patients and controls, FokI, ApaI, TaqI, and KT280406 were validated $(p>0.05)$ by the Hardy-Weinberg equilibrium (HWE).

In the genetic analysis, "C" was identified as a risk allele $(p=0.001)$ from FokI (rs2228570), while the risk genotype was CC $(p=0.0015)$ making the population at risk of T1D development. Allele "T" from ApaI (rs7975232) was found to be significant with T1D $(p=0.036)$, but at the genotype level "TT" and "TG," significant association was detected between T1D and the studied SNP $(p=0.014)$. No significant difference was observed for TaqI among patients and controls for allelic and genotypic frequencies $(p>0.05)$. A novel SNP was identified as a result of the sequencing shown in Figure 2 about $62 \mathrm{bp}$ downstream from the ApaI polymorphic site and submitted to NCBI (GeneBank Acc number KT280406); the detected mutation was G into C. This novel SNP was only identified in $4.18 \%$ of patients while it was not found in the controls.

Protein alignment showed that tryptophan changes into arginine in FokI with a change in allele whereas no change in amino acid occurred in TaqI sites.

Haplotype analysis depicted both the protected and susceptible haplotypes for T1D. For the four genetic polymorphisms, haplotypes CCGC, CCGG, CCTC, and CCTG were significantly associated with T1D $(p<0.01)$. However, the frequency of CTGG and CTTG was higher in controls $(0.933,0.067$, resp. $)$ as compared to patients $(0.051,0.000$, resp.); so they were protective against T1D development $(p<0.01)$, as shown in Table 3 . A correction with eight gives only significance for the CTTG haplotype which was protective against T1D development.
Linkage disequilibrium (LD) of genetic variants revealed the possible genetic recombinations ( $\left.\mathrm{D}^{\prime}\right)$ between the SNPs within loci. Strong LD was described in VDR gene (rs2228570, rs7975232, and KT280406) with 89.8\% $\left(\mathrm{D}^{\prime}=0.898\right)$ recombination. Correlation between rs7975232, rs2228570, and KT280406 revealed that these SNPs are not a good predictor of each other $\left(r^{2}=0.150\right)$ (Figure 3).

\section{Discussions}

The results of the present study revealed the existence of an association between VDR-FokI, VDR-ApaI polymorphisms, and T1D in the Pakistani population. The association of the $V D R$ gene polymorphism at four polymorphic sites (FokI, ApaI, KT280406, and TaqI) with T1D was examined in the present study. In the current study, ApaI does violate HWE $(p<0.05)$. This might be because Pakistan is a multicultural country with specific traditions which were followed for generations. Among those traditions, one of the most common traditions is intercaste marriages and absence of random mating, ultimately reducing genetic recombination. These also might be the reason for the HWE violation.

The current study reported that FokI polymorphism significantly $(p=0.001)$ increased the chances of disease development in the Pakistani population. However, the frequency of the FokI " $\mathrm{C}$ " allele was higher in cases in Hungary [18]. The findings on Dalmatian and Japanese populations were in line with the results of our study that the FokI restriction site was significantly associated with T1D $[19,20]$. In contrast with the current results, the findings on two subpopulations of Spain and Iran reported no association of FokI polymorphism with T1D. Moreover, the frequency of the CT allele was reported to be higher in cases as compared to controls in the Iranian Population [21,22].

No significant genotypic association was observed between ApaI polymorphism and T1D in the current study; however $(p<0.05)$, in the Taiwanese population, a significant association was reported between the ApaI polymorphism and the onset of T1D [23]. In line with the present observation, studies on Greece, Finland, and Norway reported that no association exists between ApaI polymorphism with the development of T1D [24-26].

The present study demonstrated that the $\mathrm{C}$ allele of TaqI was frequently present in both the case and control, and no association exists between TaqI polymorphism and T1D development in the Pakistani population. In contrast to our study, it was reported that the $\mathrm{T}$ allele was more common in $79.5 \%$ of healthy subjects as compared to diseased, and a significant association exists between TaqI polymorphism and T1D [27]. Genetic heterogeneity was reported to be influenced by the TaqI polymorphism in Romanian T1D individuals and significantly associated with T1D $[20,28]$.

The effect of $V D R$ gene polymorphism on its functioning has not been completely understood, and it was considered that different SNP interactions lead to the alteration in gene functioning [25]. The current study revealed that the frequency of haplotypes CTGG and CTTG of TaqI-FokIApaI-KT280406 was significant and protects against disease development. CCGG, CCTC, and CCTG were significantly 


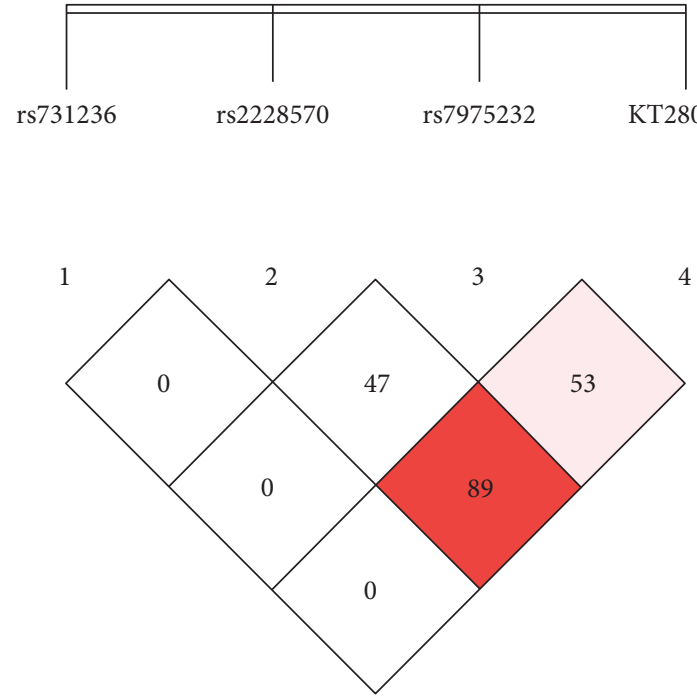

(a)
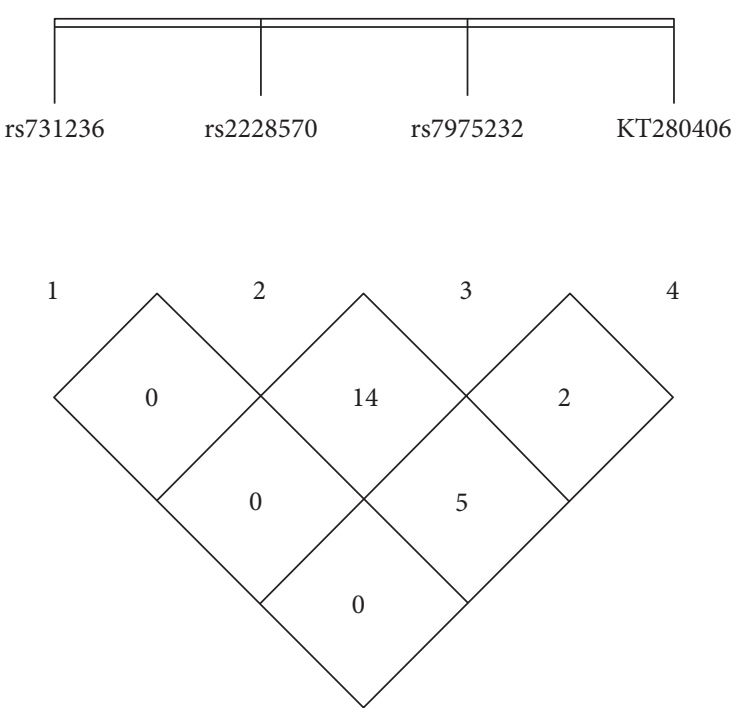

(b)

FIGURE 3: Location and map of linkage disequilibrium (LD) in SNPs at VDR gene are presented. The SNP numbers are indicated at the top of haploview. (a) $\mathrm{LD}=\mathrm{D}^{\prime}$ and (b) LD coefficient. Red = linkage is highly significant, pink = significant, and white = not significant $($ decrease in color sharpness indicated reduce chances of disease transfer to next generation).

associated $(p<0.01)$ and involved in disease development. In line with current observation, CCG was reported as a significantly associated haplotype in the German population and acts as a protective marker whereas CTG, CTT, and CCT were not associated with the haplotype of T1D [29].

A significant association between rs2228570, rs731236, rs7975232, and rs1544410 and development of T1D was reported in Taiwan, India, Hungary, German, Japan, Croatia, the Netherlands, Chile, and Spain [18, 22, 23, 29-33]. However, in Brazil, Finland, Romania, the United States, and Norway, the population lacks the association of T1D with rs731236, rs2228570, rs7975232, and rs1544410 [17-28, 34, 35].

\section{Conclusions}

Our case-control study demonstrated that VDR polymorphism in the FokI, ApaI, and KT280406 regions is susceptible to T1D development in the Pakistani population. Further studies should be carried out to determine the role of genetics in diabetes onset so that the susceptible communities can be targeted.

\section{Conflicts of Interest}

The authors declare that they have no competing interests.

\section{Acknowledgments}

The authors are thankful to the Higher Education Commission (HEC), Pakistan for funding this research. The authors are thankful to WTO Labs (UVAS) and Shalimar Hospital Lahore staff and management for their cooperation in conducting this research.

\section{References}

[1] J. C. Barrett, D. G. Clayton, P. Concannon et al., "Genomewide association study and meta-analysis find that over 40 loci affect risk of type 1 diabetes," Nature Genetics, vol. 41, no. 6, pp. 703-707, 2009.

[2] F. Pociot and M. F. McDermott, "Genetics of type 1 diabetes mellitus," Genes and Immunity, vol. 3, no. 5, p. 235, 2002.

[3] E. Y. Fung, D. J. Smyth, J. M. Howson et al., "Analysis of 17 autoimmune disease-associated variants in type 1 diabetes identifies 6q23/TNFAIP3 as a susceptibility locus," Genes and Immunity, vol. 10, no. 2, pp. 188-191, 2009.

[4] M. Karvonen, J. Tuomilehto, I. Libman, and R. LaPorte, "A review of the recent epidemiological data on the worldwide incidence of type 1 (insulin-dependent) diabetes mellitus," Diabetologia, vol. 36, pp. 883-892, 1993.

[5] J. N. Yaochite, C. Caliari-Oliveira, M. R. Davanso et al., "Dynamic changes of the Th17/Tc17 and regulatory $\mathrm{T}$ cell populations interfere in the experimental autoimmune diabetes pathogenesis," Immunobiology, vol. 218, pp. 338-352, 2013.

[6] L. Yang, J. Ma, X. Zhang, Y. Fan, and L. Wang, "Protective role of the vitamin D receptor," Cellular Immunology, vol. 279, pp. 160-166, 2012.

[7] A. Busta, B. Alfonso, and L. Poretsky, "Type 1 Diabetes - Complications, Pathogenesis, and Alternative Treatments," in Role of Vitamin D in the Pathogenesis and Therapy of Type 1 Diabetes Mellitus, C.-P. Liu, Ed., INTECH Open Access Publisher, China, 2011.

[8] H. J. Hahn, B. Kuttler, C. Mathieu, and R. Bouillon, “1, 25Dihydroxyvitamin $\mathrm{D}_{3}$ reduced MHC-antigen expression on pancreatic $\beta$-cells in vitro," Cell Transplantation, vol. 5 , p. 60, 1996.

[9] R. Riachy, B. Vandewalle, E. Moerman et al., "1, 25-Dihydroxyvitamin $\mathrm{D}_{3}$ protects human pancreatic islets against cytokine-induced apoptosis via down-regulation of the Fas receptor," Apoptosis, vol. 11, pp. 151-159, 2006. 
[10] C. Mathieu and L. Adorini, "The coming of age of 1, 25dihydroxyvitamin $\mathrm{D}_{3}$ analogs as immunomodulatory agents," Trends in Molecular Medicine, vol. 8, pp. 174-179, 2002.

[11] L. A. Crofts, M. S. Hancock, N. A. Morrison, and J. A. Eisman, "Multiple promoters direct the tissue-specific expression of novel $\mathrm{N}$-terminal variant human vitamin $\mathrm{D}$ receptor gene transcripts," Proceedings of the National Academy of Sciences, vol. 95, pp. 10529-10534, 1998.

[12] M. R. Haussler, G. K. Whitfield, C. A. Haussler et al., "The nuclear vitamin $\mathrm{D}$ receptor: biological and molecular regulatory properties revealed," Journal of Bone and Mineral Research, vol. 13, pp. 325-349, 1998.

[13] A. Batool, M. Mukhtar, I. Qayyum, and R. Shakeel, “Association of rs2476601 and rs1544410 with onset of T1D in youngsters of Lahore, Pakistan," Journal of Bioresource Management, vol. 3, 2016.

[14] M. Vidal, C. V. Ramana, and A. S. Dusso, "Stat1-vitamin D receptor interactions antagonize 1,25-dihydroxyvitamin D transcriptional activity and enhance stat1-mediated transcription," Molecular and Cellular Biology, vol. 22, pp. 2777-2787, 2002.

[15] J. F. Bach, "Insulin-dependent diabetes mellitus as an autoimmune disease," Endocrine Reviews, vol. 15, pp. 516-542, 1994.

[16] J. Sambrook, E. F. Fritsch, and T. Maniatis, Molecular Cloning, Cold spring harbor laboratory press, New York, 1989.

[17] N. Israni, R. Goswami, A. Kumar, and R. Rani, "Interaction of vitamin $\mathrm{D}$ receptor with HLA DRB1 ${ }^{*} 0301$ in type 1 diabetes patients from North India," PLoS One, vol. 4, article e8023, 2009.

[18] E. Gyürüs, "Epidemiology of type 1 diabetes in children in Hungary," Pediatric Diabetes, vol. 27, p. 26, 2012.

[19] Y. Ban, M. Taniyama, T. Yanagawa et al., "Vitamin D receptor initiation codon polymorphism influences genetic susceptibility to type 1 diabetes mellitus in the Japanese population," BMC Medical Genetics, vol. 2, no. 1, p. 7, 2001.

[20] T. Zemunik, V. Škrabić, V. Boraska et al., "FokI polymorphism, vitamin $\mathrm{D}$ receptor, and interleukin-1 receptor haplotypes are associated with type 1 diabetes in the Dalmatian population," The Journal of Molecular Diagnostics, vol. 7, no. 5, pp. 600-604, 2005.

[21] S. Bonakdaran, M. R. Abbaszadegan, E. Dadkhah, and M. Khajeh-Dalouie, "Vitamin D receptor gene polymorphisms in type 1 diabetes mellitus: a new pattern from Khorasan province, Islamic Republic of Iran/Polymorphismes du gene du recepteur de la vitamine $\mathrm{D}$ et diabete de type 1: un nouveau modele dans la province de Khorasan (Republique islamique d'Iran)," Eastern Mediterranean Health Journal, vol. 18, no. 6, p. 614, 2012.

[22] L. Audi, G. Marti, C. Esteban et al., "VDR gene polymorphism at exon 2 start codon (FokI) may have influenced type 1 diabetes mellitus susceptibility in two Spanish populations," Diabetic Medicine, vol. 21, no. 4, pp. 393-394, 2004.

[23] T. J. Chang, H. H. Lei, J. I. Yeh et al., "Vitamin D receptor gene polymorphisms influence susceptibility to type 1 diabetes mellitus in the Taiwanese population," Clinical Endocrinology, vol. 52, no. 5, pp. 575-580, 2000.

[24] H. Turpeinen, R. Hermann, S. Vaara et al., "Vitamin D receptor polymorphisms: no association with type 1 diabetes in the Finnish population," European Journal of Endocrinology, vol. 149, no. 6, pp. 591-596, 2003.
[25] S. Nejentsev, J. D. Cooper, L. Godfrey et al., "Analysis of the vitamin D receptor gene sequence variants in type 1 diabetes," Diabetes, vol. 53, no. 10, pp. 2709-2712, 2004.

[26] C. Panierakis, G. Goulielmos, D. Mamoulakis, E. Petraki, E. Papavasiliou, and E. Galanakis, "Vitamin D receptor gene polymorphisms and susceptibility to type 1 diabetes in Crete, Greece," Clinical Immunology, vol. 133, no. 2, pp. 276-281, 2009.

[27] E. Ramos-Lopez, T. Jansen, V. Ivaskevicius et al., "Protection from type 1 diabetes by vitamin D receptor haplotypes," Annals of the New York Academy of Sciences, vol. 1079, no. 1, pp. 327-334, 2006.

[28] C. Guja, S. Marshall, K. Welsh et al., "The study of CTLA-4 and vitamin D receptor polymorphisms in the Romanian type 1 diabetes population," Journal of Cellular and Molecular Medicine, vol. 6, no. 1, pp. 75-81, 2002.

[29] M. A. Pani, M. Knapp, H. Donner et al., "Vitamin D receptor allele combinations influence genetic susceptibility to type 1 diabetes in Germans," Diabetes, vol. 49, no. 3, pp. 504-507, 2000.

[30] M. F. McDermott, A. Ramachandran, B. W. Ogunkolade et al., "Allelic variation in the vitamin D receptor influences susceptibility to IDDM in Indian Asians," Diabetologia, vol. 40, no. 8, pp. 971-975, 1997.

[31] M. C. Lemos, A. Fagulha, E. Coutinho et al., "Lack of association of vitamin $\mathrm{D}$ receptor gene polymorphisms with susceptibility to type 1 diabetes mellitus in the Portuguese population," Human Immunology, vol. 69, no. 2, pp. 134-138, 2008.

[32] Y. Motohashi, S. Yamada, T. Yanagawa et al., "Vitamin D receptor gene polymorphism affects onset pattern of type 1 diabetes," The Journal of Clinical Endocrinology \& Metabolism, vol. 88, no. 7, pp. 3137-3140, 2003.

[33] J. S. Pedro, J. R. Bilbao, G. Perez de Nanclares, J. C. Vitoria, P. Martul, and L. Castano, "Heterogeneity of vitamin D receptor gene association with celiac disease and type 1 diabetes mellitus," Autoimmunity, vol. 38, no. 6, pp. 439-444, 2005.

[34] O. M. Hauache, M. Lazaretti-Castro, S. Andreoni et al., "Vitamin D receptor gene polymorphism: correlation with bone mineral density in a Brazilian population with insulindependent diabetes mellitus," Osteoporosis International, vol. 8, no. 3, pp. 204-210, 1998.

[35] J. H. Zhao, D. Curtis, and P. C. Sham, "Model-free analysis and permutation tests for allelic associations," Human Heredity, vol. 50, no. 2, pp. 133-139, 2000. 



Submit your manuscripts at

https://www.hindawi.com
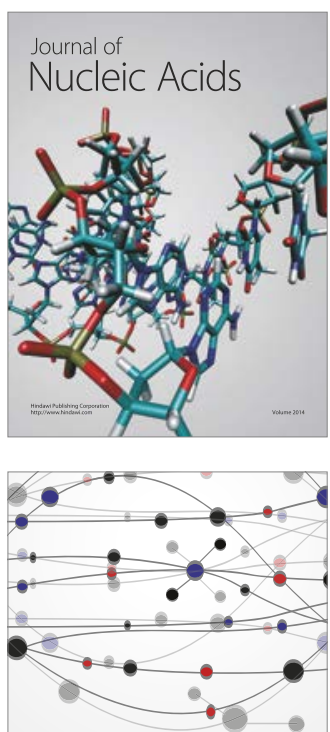

The Scientific World Journal

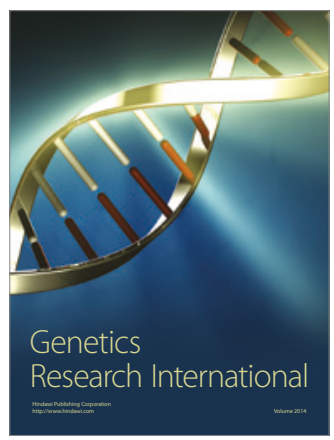

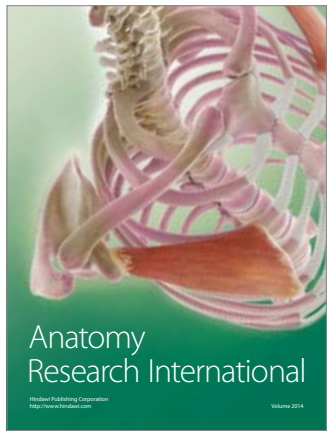

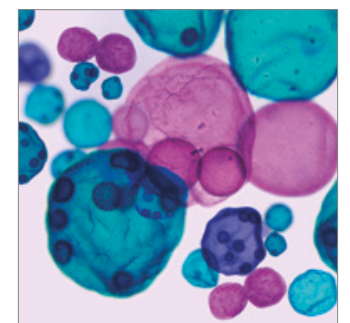

International Journal of Microbiology
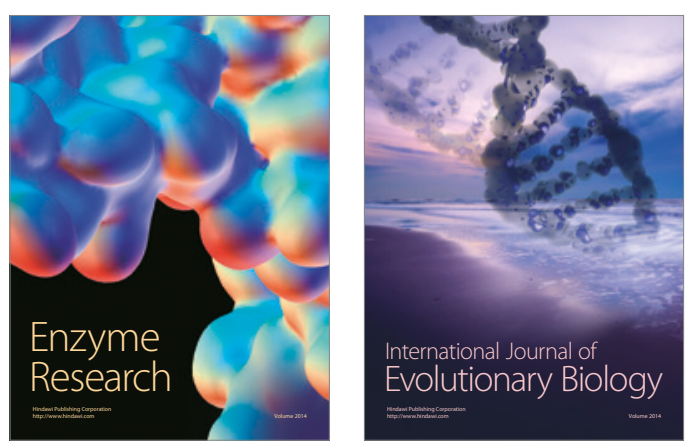
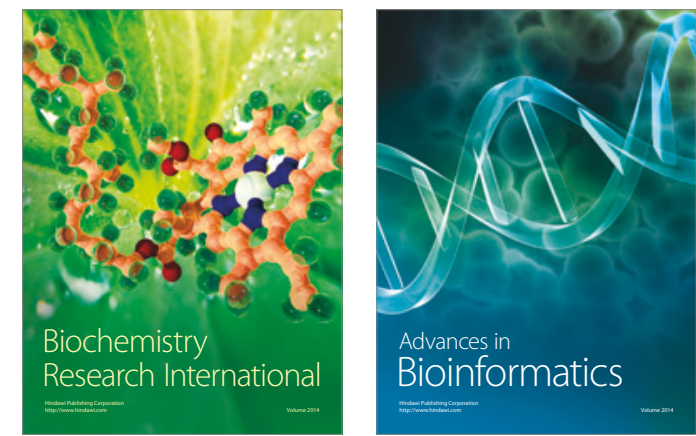

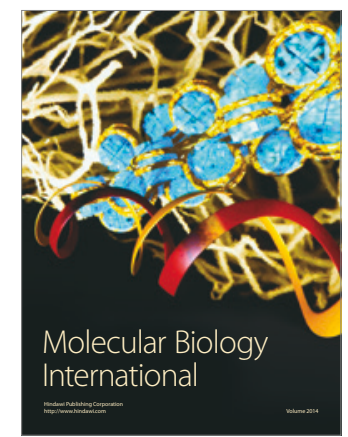

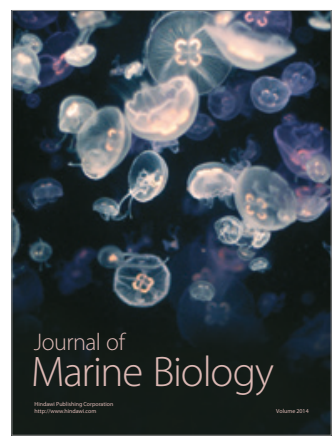

